\title{
Die verhouding tussen Psigologie en Praktiese Teologie - aspekte van die onderlinge waarde van dié verhouding
}

\author{
S.F. Kruger \& C.J.H. Venter \\ Skool vir Kerkwetenskappe (Praktiese Teologie) \\ Potchefstroomse Universiteit vir $\mathrm{CHO}$ \\ POTCHEFSTROOM \\ E-pos: sfk@lantic.net \\ skwcjhv@puknet.puk.ac.za
}

\begin{abstract}
The relation between Psychology and Practical Theology - aspects of the mutual value of this relation

This article focuses on issues of the praxis in Practical Theology. As far as the extent of the praxis is concerned, attention is directed to praxis as the psychological disposition of people. The interaction between Scripture and praxis is investigated, incorporating the views of several exponents in this field of study. The conclusion arrived at is that in practical-theological research, the value and function of the praxis, in the sense of the psychological disposition of people, are to be sought on a level between the functions of clarifying and the setting of norms; between reality and truth and between sources on reality and the Source of truth.
\end{abstract}

Praktiese Teologie onderskei homself van die ander teologiese dissiplines deur sy bipolêre fokus: enersyds is die Skrif die studieobjek en andersyds die konkrete werklikheid, oftewel die praxis (vgl. Nel, 1991:1). Deur die jare het die klemplasing tussen hierdie twee pole gewissel. So het die Praktiese Teologie óf sy deduktiewe funksie óf sy induktiewe funksie beklemtoon. Hierdie tweede pool (die praxis) as studie-objek kan baie wyd wees, aangesien die konkrete werklikheid 'n verskeidenheid gestaltes kan aanneem.

In hierdie artikel word ten aanvang, terwille van perspektiefverbreding en oriëntering, die verskillende gestaltes van die praxis, soos wat dit binne die fokus van die Praktiese Teologie kan val, kortliks omlyn. Die aard van die verhouding tussen teorie en praxis is ook van belang vir die onderwerp en word daarom kortliks gestel. Daarna word op een spesifieke gestalte gekonsentreer, naamlik die praxis as produk van die psigologiese wetenskappe. 
Die uiteindelike oogmerk van hierdie artikel is om die plek en waarde van die Psigologie vir die Praktiese Teologie en vir die teologiese pastoraat vas te stel. Dit word as deel van die praktykteoretiese arbeid van die Praktiese Teologie beskou om die funksionele waarde van die praxis (hier in besonder die resultaat van die Psigologie) deurlopend aan te toon.

\section{Die verhouding teorie en praxis}

Dit is van belang vir die onderwerp om die aard van die verhouding tussen teorie en praxis vas te stel.

\subsection{Die wisselende klemplasing tussen teorie en praxis}

Deur die jare het die klemplasing gewissel tussen teorie en praxis. Jonker (1968:9) beklemtoon byvoorbeeld die teorie en sien die Skrif as studie-objek en waarskynlik onder invloed van Kuyper (vgl. 1909:538) wil Jonker (vgl. 1968:24) die vak toespits op die ampswerk en diens binne die kerk.

Hierteenoor sien Schleiermacher (1977:99) die empiriese werklikheid (praxis) as die objek van hierdie vak. Ook Zerfass (1974:164-177) plaas die klem op die empiriese, maar tog met balans. In navolging van Habermas plaas hy Praktiese Teologie as handelingswetenskap. Tans word die begrip handeling redelik algemeen gebruik om die gesigspunt wat die Praktiese Teologie op die werklikheid het te beskryf, met 'n latere uitbreiding na kommunikatiewe handeling (vgl. Pieterse, 1991:43-45). Hierdeur word hierdie vak aangedui as 'n aksie-georiënteerde of 'n gedragsgeoriënteerde vak (vgl. Louw, 1996:23). Praktiese Teologie is volgens Firet (1980:16) die teologiese teorie aangaande die handelingsisteme wat die kom van God tot die mens intermediërend dien.

\subsection{Die aard van die verhouding teorie en praxis}

Binne die Praktiese Teologie is aldus algaande wegbeweeg van 'n dualistiese benadering tot die verhouding teorie en praxis. Klem is eerder geplaas op die spanning (vgl. Nel, 1991:12), die wederkerigheid (vgl. Louw, 1996:33), die interaksie (vgl. Firet, 1980:12) en die komplementêre waarde van teorie en praxis (vgl. Van der Ven, 1993:97), wat egter nie identifikasie beteken nie (vgl. Heitink, 1993:150). Van der Ven (1988: 18) beskryf die formele objek van hierdie vak as die dialektiese verhouding tussen wat die godsdienstige praxis is en wat dit behoort te wees.

Venter (1996:26, 27), in aansluiting by Heyns en Pieterse (1990:6 e.v.), volg die voetspoor van Zerfass, Firet en Van der Ven (soos hierbo genoem), maar stel baie duidelik dat Praktiese Teologie nooit van sy 
teologiese aard en normatiewe fundering ontneem mag word nie. Louw (1996:23 e.v.) is versigtiger met ' $n$ aansluiting by onder andere Van der Ven en hy lewer kritiese kommentaar op Van der Ven se basisteorie. Hy stel oortuigend dat daar 'n diskontinuïteit bestaan tussen menslike handeling as kenbron en God se handeling (of God se praxis) en dat daar êrens 'n punt kom waar menslike handeling as kenbron stol, wat beteken dat geen menslike handeling jou direk toegang tot God se handeling gee nie (Louw, 1996:37).

Wat uit bostaande belangrik is vir die onderwerp in hierdie artikel, is die klem op die wisselwerking en komplementêre aard binne die verhouding teorie en praxis sowel as die handelingsgestalte wat as sisteemteorie die interaksie tussen Skrif en praxis aandui. Die twee werklikhede binne die Praktiese Teologie word dus sterk geïntegreerd hanteer.

\section{Die omvang van die praxis}

Dit is ook belangrik om die verskillende gestaltes van die praxis kortliks te omlyn. Hierdeur kan die psigologiese gestalte van die praxis binne 'n breër perspektief verstaan word.

Drie gestaltes van die praxis kan onderskei word: binne die kerk (of geloofsgemeenskap) en binne en buite die kerk (die breë gemeenskap). Laasgenoemde differensieer verder in die onderskeiding tussen die maatskaplike of sosiale dimensie en die persoonlik-psigologiese dimensie. So word drie terreine onderskei wat vervolgens aan die orde gestel sal word.

\subsection{Die praxis as kerklike praktyk}

Vir Zerfass (1974:167) is praxis die Christelik-kerklike handelinge oftewel 'n (bestaande of nuwe) kerklike praktyk. By Jonker (1968:9) is dit deel van die funksie van die Teologie (diakoniologie) om antwoorde te bied op praktiese vrae. Hierdie praktiese vrae setel by Jonker amper uitsluitlik in die kerklike praktyk. Trimp (1972:148 e.v.) sluit hierby aan en stel dat die Praktiese Teologie die teorie van die praxis van die kerk is.

Firet (1980:10) plaas 'n nuwe klem in die sin dat hy onder praxis nie bloot die menslik-gevormde praktyk verstaan nie, maar die praxis van God. Dingemans (1986:16) se gevolgtrekking is dat die praxis alle handelinge van die Christelike geloof en lewe kan insluit soos wat dit voorkom in die kerklike geloofsgemeenskap.

In Suid-Afrika is dit veral Pieterse (1994:93 e.v.), sowel as Heyns en Pieterse (1990:23-32), maar ook Venter (1996:27, 1995:200, 1992:44) en Louw (1996:23 e.v.) wat gedurende die afgelope dekade die promi- 
nensie van die kerklike praxis as deel van Praktiese Teologie beklemtoon het.

\subsection{Die praxis as die maatskaplike scenario}

Die praxis kan ook dui op die sosiale werklikheid, wat onmiddellik die kontak tussen Teologie en die Sosiale Wetenskappe op die agenda plaas. Hierdie verhouding lê dus op metavlak.

Van der Ven (1993:97) sowel as Louw (1996:33) beskryf die praxis as (onder andere) die kulturele en sosiale dimensie van die moderne samelewing. Die maatskaplike taak van die Praktiese Teologie word deur Louw (2001:11) besonder sterk beklemtoon. Ook McCann (1983: 109) sien Praktiese Teologie as 'n vak met ook 'n sosiale agenda. Hy verwys na die maatskaplike probleme in die tyd van Jesus se lewe op aarde wat ook Jesus se agenda bepaal het. Browning (1983:192/3) beklemtoon die versorgingsmotief (care) binne die Praktiese Teologie en stel dat die praktiese (of spesifiek pastorale) teoloog in die konkrete werklikheid behoort te funksioneeer binne die Christelike en sosiale konteks. Jonker (1983:18) noem dat die Teologie 'n hernude aandag vir die konkreet-lewende mens met sy sosiale probleme ontwikkel het. Heitink (1998:190 e.v., 1984:276) het hiertoe 'n besondere bydrae gelewer met sy onderskeiding van lewenshulp en geloofshulp. Hy stel dat individuele pastoraat ook altyd kontekstuele pastoraat is (Heitink, 1998:208).

Dit is dus duidelik dat die breë gemeenskap (sosiaal, polities, kultureel, maatskaplik bepaald) ook binne die fokus van die Praktiese Teologie kan val.

\subsection{Die praxis as die psigologiese gesteldheid van die mens}

Die eerste aanduiding van 'n verhouding tussen godsdiens en die mens as psigologiese wese dateer waarskynlik uit die tydperk voor die opkoms van sekularisme (wat terminologies in 1851 gemunt is). Toe alreeds is die mens se psigologiese en persoonlike lewe godsdienstig uitgedruk (vgl. Smith, 1978:124). Die praxis is in hierdie geval die psigologiese funksionering van die mens, wat in die lig van die resultate van die Psigologie verstaan moet word en wat individueel-idiografies en/of korporatief-nomoteties belig kan word.

Hierdie gestalte van die empiriese werklikheid sluit nouer aan by die onderwerp wat in hierdie artikel behandel word en word vervolgens meer uitgebreid behandel. 


\section{Interdissiplinêre kontak tussen Teologie en Psigologie}

Hierdie verhouding tussen godsdiens en die psigologiese gesteldheid van die mens lê op metavlak en noodsaak dus metakommunikasie. In verband met die interdissiplinêre kontak tussen die Teologie en die Gedragswetenskappe word hier gewys op die samewerking tussen hierdie dissiplines wat in die VSA in bepaalde kringe sterk beklemtoon word - soos wat blyk uit die volgende:

- Die bestaan van die Christian Association for Psychological Studies (CAPS) met sy invloedryke tydskrif Journal of Psychology and Christianity bevestig die nou kontak tussen hierdie twee dissiplines, alhoewel hier meer vanuit psigologiese gesigspunt gewerk word. Die jarelange redakteur van hierdie tydskrif, J. Harold Ellens, erken dat die vakdissiplines Teologie en Psigologie albei 'n wetenskaplike aard het, maar hy erken ongelukkig nie die normatiewe karakter van die Teologie nie (Ellens, 1997:5 e.v.).

- Die verskyning van die boek Personality and Religion - the Role of Religion in Personality Development (1970) met William A. Sadler as redakteur, is noemenswaardig, nie alleen vanweë die besondere tema nie, maar ook vanweë die feit dat hierdie bundel bydraes bevat van wêreldbekende gesaghebbendes (vanuit die Psigologie): Sigmund Freud (vgl. 1970:47-56), Gordon Allport (vgl. 1970:73-88), Erich Fromm (vgl. 1970:117-134) en Carl Jung (vgl. 1970:135-145).

Die verhouding tussen Praktiese Teologie en die Psigologie was oor jare heen in die brandpunt van besinning. Hiltner (1958:177 e.v.) het byvoorbeeld 'n sielkundige beklemtoning gegee aan die Praktiese Teologie (wat hy Pastorale Teologie genoem het). $\mathrm{Na}$ Hiltner was daar heelwat pogings om die Praktiese Teologie en die veld van die Psigologie met mekaar te verbind (vgl. Browning, 1983:16).

Vir die wetenskaplike besinning oor die verhouding tussen Teologie en Psigologie het die sielkundige, William James (1842-1910) in sy boek The Varieties of Religious Experience (1929) grondliggende werk gedoen deur 'n filosofiese raamwerk te bied waarop baie latere pastorale teoloë voortgebou het (vgl. James, 1929:1-7). Ellens (1997:7) noem hom die "unavoidable rock to which one is anchored". James sê dat geen psigologiese studie van die mens volledig is as dit nie eers kennis geneem het van die godsdiens van die mens nie (vgl. Sadler, 1970:3). Sadler $(1970: 2,5)$ bou sterk op James se filosofie en volgens Sadler is die kontakpunt tussen Teologie en Psigologie die feit dat albei dieselfde wortels het: 'n studie van die menslike natuur. 
Carter en Narramore (1979:117) het die integrasiemodel geskep. Hierdie integrasie is volgens hulle werkbaar solank dit Christelike en sekulêre konsepte met mekaar in verband bring (wat deur Pruyser meesterlik gedoen word - 1968:47 e.v.), en verder die onderskeie wyses van dink en funksionering met mekaar versoen. Cole (1998:210 e.v.) evalueer die integrasieparadigma wat vir twintig jaar deur die Christian Association for Psychological Studies gebruik is. Sy hoofbeswaar is dat die uitgangspunte van die Teologie en die Psigologie verskil. Hy stel dat die Psigologie met 'n werklikheid werk wat nie aan God behoort nie terwyl daar volgens die Skrif nie so 'n werklikheid bestaan nie. Ellens (1997:5 e.v.) verwerp die idee van integrasie en praat van 'n tussenvlak waarin elke dissipline sy eie aard behou.

Opsommend: Die bestaan van 'n verhouding tussen Praktiese Teologie en praxis (as psigologiese bestaan van die mens) is hiermee bevestig. Ook die verskillende perspektiewe op die inhoud van die praxis en die konkrete gebruik daarvan is belig, naamlik praxis soos verstaan in die lig van die kerklike praktyk, die sosiaalwetenskaplike produk en die psigologiese produk. Die verhouding teorie en praxis, spesifiek as die psigologiese produk, kan problematies wees. Voorlopig word die volgende egter gestel: ongeag die uitgangspunte van die Psigologie, kan die (wetenskaplike) resultate daarvan die Teologie tog tot hulp wees om die empiriese werklikheid te verstaan, solank hierdie resultate telkens binne sy teoretiese oriëntasie, wat tog 'n waardestelsel bevat, verstaan word. Hierdie verhouding word egter hieronder verder ondersoek.

\section{Die tussenvlak in die verhouding tussen Psigologie en Teologie}

\subsection{Oorsig}

Dit het duidelik geword dat die praxis, as studie-objek van die Praktiese Teologie, ook die psiogologiese gesteldheid van die mens kan insluit. Dit het verder duidelik geword dat praxis en teorie nie dualisties benader kan word nie, maar eerder in terme van die komplementariteit binne hierdie verhouding. Met hierdie benadering gaan vervolgens gelet word op die komplementêre waarde van die Psigologie vir die Praktiese Teologie.

Vir die verstaan van die mens as persoonlik-psigologiese werklikheid is die Praktiese Teologie afhanklik van die resultate van die Persoonlikheidsielkunde. Dit plaas die vraag na 'n moontlike sensitiwiteit in die verhouding tussen Teologie en Psigologie in die aandagsveld. 
Dit word as gegewe hier gestel dat metakontak, ook in die praktiese beoefening van die herderlike bediening deur die pastor of teoloog, inhou dat daar van die kant van die pastor met omsigtigheid behoort gewerk te word sodat die professionele terrein van die psigoloog nie betree word nie. Hierdie omsigtigheid is nie slegs eties gebiedend nie, maar dit sou onwetenskaplik van die pastor wees om op die professionele terrein van die psigoloog te werk terwyl hy nie daarvoor opgelei is nie. Die interdissiplinêre kontak sou wel kan beteken dat die teoloog (en Teologie) kennis neem van die resultate van die Psigologie en ook daarvan gebruik maak met die nodige sensitiwiteit en moontlike leiding van 'n psigoloog.

Indien aanvaar word dat in hierdie opsig nie bloot twee werklikhede (Teologie en Psigologie) op die tafel is nie, maar ook 'n derde, naamlik die verband tussen die twee, kan verder by Ellens (1997:5) aangesluit word in sy gebruik van die term tussenvlak. Die tussenvlak is die modus van die werking tussen die twee werklikhede of dissiplines. Die waarde van die psigologiese praxis lê in hierdie geval in dit wat in die tussenvlak afspeel. Derhalwe word die aard van die tussenvlak vervolgens aan die orde gestel.

Dit wil volgens kontemporêre literatuur voorkom of die verhouding tussen Teologie en Psigologie hoofsaaklik vanuit die Psigologie benader word. Ogletree (1983:83 e.v.) benader byvoorbeeld hierdie interdissiplinêre kontak vanuit 'n psigologiese gesigspunt as hy stel dat psigologiese modelle of (bv. kommunikasie-) tegnieke instrumenteel die effektiwiteit van die praktiese teoloog moet verhoog. Roscam Abbing (1981:2 e.v.) sowel as Zwergel (1976:9 e.v.) bestudeer die religieuse mens vanuit die sogenaamde godsdienspsigologie of Religionspsygologie. Ook Allport (1973:54 e.v.) bestudeer die mens as godsdienstige wese bloot vanuit die Psigologie. In hierdie voorbeelde is die godsdiens of godsdienstige mens die wetenskapsobjek van die Psigologie. Die resultate van hierdie wetenskap is bedoel om vir die teologie bruikbaar te wees.

Hiltner (1958:192) sluit hierby aan deur aan die gedragswetenskappe 'n verstaansfunksie toe te ken waardeur die praktiese teoloog in staat gestel word om die kontemporêre mens te begryp in sy optrede. Die rigting van beïnvloeding is dus vanaf die Psigologie na die Teologie. Tog geskied Hiltner se benadering van hierdie verhouding vanuit die gesigspunt van die Teologie (sy term is Pastorale Teologie). Ook Möller (1964: 59 ) benader hierdie verhouding vanuit 'n teologiese gesigspunt. Sy standpunt is dat die Psigologie nooit 'n Begrundings-funksie kan hê nie; dit bied slegs hulp, soos wat 'n bril 'n mens beter laat lees. 
Ellens (1997:8) beredeneer die verhouding tussen Teologie en Psigologie as 'n terminologiese vraagstuk. Hy stel dat die term "integrasie" nie bevredig nie aangesien twee ongelyksoortige dissiplines geïntegreer moet word - en dit kan nie. Hy beskou die formulering: "wedersydse verligting of verheldering" (mutual illumination) as 'n werkbare term vir die beskrywing van hierdie aksie wat op die tussenvlak plaasvind. Met die begrip "verligting" bedoel Ellens (vgl. 1997:16) dat die Psigologie, wat gelowig voor die aangesig van God beoefen word, in die (wat hy noem) menslike dokument wat hy bestudeer, daardie selfde aangesig van God kan sien en op hierdie wyse verhelderend inwerk op die Teologie. Net so kan die Teologie wat voor die aangesig van God boefen word, in die Skrif daardie selfde aangesig sien en dit as 'n verhelderende werking aan die Psigologie deurgee. Ellens se tese is dat elkeen van die twee dissiplines 'n lens is waardeur diep in sy eie wetenskaplike arena ingesien kan word. Net so is elke dissipline 'n lens deurdat dit lig aan die ander dissipline bring wat die betrokke ander dissipline tot hulp is om die aangesig van God duideliker in sy eie studieveld te kan raaksien. Sy bedoeling is dat die Psigologie die Teologie help om die mens as studieobjek beter te verstaan en daarom duideliker die gesig van God daarin waar te neem.

Sadler (1970:2) se standpunt sluit hierby aan as hy sê dat persoonlikheid en godsdiens dieselfde wortels het. Om die verborge aspekte van die een te ontdek lei tot groter insigte by die ander (Sadler, 1970:3).

Die aard van die interaksionele dimensie kan ook motiefverhelderend wees. Gibson (1995:58 e.v.), Crabb (1987:171 e.v.), Allport (1970:73 e.v.) en Allen en Spilka (1967:191 e.v.) gebruik psigologiese meting om verkeerde motiewe by (veral) kerkgangers te identifiseer. Hierdeur word insig aan die Teologie gegee waardeur die kerk sy bedieningseffektiwiteit kan verhoog. Ook Ellis (1996:11) verduidelik vanuit die Psigologie die dinamika van die rasionele onderbou as determinant van menslike gedrag. Insig in hierdie dinamika kan ook verhelderend vir die praktiese teoloog wees. Die tussenvlak behels dus 'n verligtings- of verhelderingsfunksie wat die Teologie in staat stel om sy verstaansfunksie te vervul.

\subsection{Sistematisering}

Bostaande stof word vervolgens gesistematiseer en uitgebrei sodat die funksie van die tussenvlak - dié tussen Teologie en Psigologie - soos volg beskryf kan word. Dit word gedoen mede in die lig van die aard van die verhouding tussen teorie en praxis soos hierbo uiteengesit.

Daar behoort onderskei te word tussen

- 'n verhelderende funksie en 'n normerende funksie;

- tussen werklikheid en waarheid; 
- en tussen werklikheidsdokument en waarheidsbron.

Met hierdie onderskeiding word die Skrif op 'n ander vlak geplaas as enige ander werklikheid binne die skopus van die Praktiese Teologie.

\subsubsection{Verhelderende funksies}

Verhelderende funksies stem ooreen met Zerfass se hermeneutiese wisselwerking (vgl. Venter, 1992:44) en sluit die volgende in:

\section{- Verstaansfunksies}

'n Verstaansfunksies veronderstel dat dieselfde objek ondersoek word vanuit verskillende gesigspunte. So bestudeer nie net die Psigologie nie, maar ook die Teologie (onder andere) die mens. Dit is nie vreemd vir die Praktiese Teologie om ook die eksistensiële mens binne sy fokusveld te bring nie (vgl. Smuts, 1989:viii). Die Skrif handel (onder meer) ook oor die mens. Daarom is dit vir die Praktiese Teologie nodig om dieselfde mens waarvan die Skrif leer, ook in sy kontemporêre leefwêreld te ken met die doel om hom (met behulp van die Psigologie) te verstaan, sy tipiese reaksies op sy leefwêreld te begryp, om gevestigde denk- en gedragspatrone te onderken en om onderliggende motiewe en vormingsagente te onderskei en die dinamika daarvan te verstaan. Die resultate van elkeen van die genoemde dissiplines bring wedersydse begrip en verheldering. Vir die Praktiese Teologie beteken dit dat die teoloog nou die eksistensiële funksionering van die mens beter kan verstaan en in sy bediening daarby kan aansluit.

In die genoemde gevalle is die Psigologie die lig en die Teologie word daardeur verlig, wat nie aan die Psigologie 'n normatiewe aard gee nie. Die Psigologie is bloot 'n godgegewe instrument waardeur God se werklikheid bekyk en ontleed kan word. Die lig van die Psigologie op die kontemporêre mens kan die praktiese teoloog se verstaansvaardigheid en gevolglike bediensgseffektiwiteit verhoog.

Daarbenewens is die Teologie ook ' $n$ lig vir die Psigologie. Hierdie verstaan van menslike gedrag geskied egter nie net in die lig van psigologiese analises nie. Die mens word per slot van sake eers werklik verstaan wanneer sy gedrag bekyk word in die lig van sy beeldskap - en gevolglike beeldverlies - en uiteindelike beeldherstel deur Christus. Die Psigologie kan vir homself nie 'n verstaansoutonomiteit toeëien nie. Daar moet gevolglik gewaak word teen 'n eksklusiewe eenrigtingbeïnvloeding binne hierdie tussenvlak. 


\section{- Teikenduidingsfunksie}

Hierdie funksie sluit baie nou aan by die verstaansfunksie, maar word tog daarvan onderskei aangesien dit 'n eie beskrywing het.

Indien die mens, as objek van praktiese herderlike bediening, nie deeglik verstaan word nie, kan die herderlike bediening gevaar loop om die teiken totaal te mis of om met 'n onvanpaste lading op die teiken aan te lê. Sonder deeglike kennis van die bedieningsobjek kan die herderlike bediening homself uitrangeer tot 'n oneffektiewe en kragtelose periferiese handeling.

Die waarde van hierdie teikenduidingsfunksie lê daarin dat dit 'n probleemteiken of versteurde area in die praxis noukeurig kan aandui. Toerustende pastorale bediening geskied nie in 'n lugleegte nie. Die effektiwiteit van pastorale bediening hou direk verband met die vraag of die gewenste teiken getref is. Die mate van aansluiting tussen die praxisprobleem en die pastorale beantwoording daarvan bepaal die relevansie en effektiwiteit van die bediening. Pastorale handelinge wat die kol mis, beteken verspilde tyd in God se koninkryk!

\section{- Motiveringsfunksie}

Dit is nie alleen van belang dat die teiken sekuur getref sal word nie, maar ook dat daar met 'n gepaste lading aangelê sal word. Indien met swak toerusting op 'n ernstige probleem gefokus word, kry die pastorale arbeid 'n oneffektiewe bedieninggestalte. Zerfass se wendingsartikel van 1974 het immers juis die lig gesien vanweë die kragtige motivering wat deur die versteurde praxis veroorsaak is en wat ' $n$ sterk aandrang tot aksie (handelingsdruk) by die praktiese teoloog veroorsaak: Es muß etwas geschehen! 'n Motiveringsfunksie sal egter alleen die gewenste handelingsdruk veroorsaak wanneer die praxis in spanning staan met 'n genormeerde werklikheid. Om Zerfass se voorbeeld (vgl. 1974:167) te gebruik: indien erediensbywoning verswak, sal dit op sigself nie 'n aandrang tot optrede veroorsaak nie (behalwe miskien om finansiële redes). Eers wanneer die beginsel van Hebreërs 10:24, 25 verhelderend inspeel op die betrokke praxis, ontstaan 'n kreatiewe spanning.

\section{- Kontrolerende funksie}

Die empiriese werklikheid het ook 'n kontrolerende funksie. Dit word 'n toets of 'n praktykteorie effektief werk en kan met lakmoes vergelyk word. Hierdie onderskeiding sluit aan by Habernas se verifikasiebeginsel wat beteken dat ' $n$ kritiese teorie uiteindelik net in ' $n$ bevrydende praxis geverifieer kan word. Hier is 'n waarskuwing egter gepas, naamlik dat hierdie funksie op pragmatistiese wyse kan werk en dat die normatiewe hierdeur gerelativeer kan word. 
By verhelderende funksies is die rigting van beïnvloeding veral vanaf die empirie na die teorie, of vanaf die Psigologie na die Teologie.

\subsubsection{Normerende funksies}

Normerende funksies sluit die volgende in:

\section{- Deontologiese funksie}

Deontologiese refleksie vind plaas tydens teorievorming, spesifiek wat die basisteorie betref waarin norme neergelê word. ' $n$ Teorie op sigself het nie veel waarde nie. Dit is alleen wanneer die teorie op die tussenvlak beweeg en krities inspeel op die empirie dat die genoemde kreatiewe spanning ontstaan en die basisteorie funksioneel word.

\section{- Toerustende funksie}

Nadat 'n kreatiewe spanning bevestig is, bestaan daar druk of aandrang in die tussenvlak. Hierdie druk motiveer die verwerkliking van 'n kreatiewe handeling. Die oogmerk van hierdie handeling is toerusting tot konkrete lewensverandering. Hierdie verandering vind eerstens plaas op persoonlike vlak, daarna op korporatiewe vlak binne die kerklike praxis en uiteindelik op sosiaal-maatskaplike vlak. Toerustende handelinge het, in algemene terme gestel, die doel om reg te maak wat verkeerd is of om aan te vul wat kortkom.

\section{5. 'n Illustrasie}

Ter wille van konkretisering word bostaande uiteensetting van die verhouding tussen Psigologie en Teologie geillustreer aan die hand van die psigoloog Gordon Allport (1897-1967) se ondersoeke na en die verbandlegging tussen 'n persoon se psigologiese gesteldheid en sy godsdienstige oriëntasie. Hierdeur wil ons aantoon dat die Psigologie verhelderend kan inspeel op die veld van die Praktiese Teologie. Allport word binne die Psigologie met besondere respek bejeën (vgl. Möller, 1996:290).

Allport (1970:83) maak 'n insiggewende opmerking as hy sê: "Now many investigations have shown that regular and frequent church attenders harbour by and large less ethnic and social hostility than do members who are casual about their attendance". Hy gee verder perspektiewe vanuit 'n persoonlik-psigologiese gesigspunt (1970:83-86) wanneer hy twee aspekte van persoonlikheid onderskei wat godsdiensoriëntasie aandui, naamlik:

- die ekstrinsieke godsdienstiggeoriënteerdes en die

- intrinsieke godsdienstiggeoriënteerdes. 
'n Mens se godsdienstige oriëntasie word volgens Allport (1960:266) ingeweef in die wese van 'n persoon se persoonlikheid self. Hierdie oriëntasie lê op 'n kontinuumlyn waarvan die twee pole ekstrinsiek en intrinsiek is (1960:265). Aan hierdie oriëntasies word vervolgens aandag gegee.

\subsection{Die ontstaan van ekstrinsieke en intrinsieke godsdiens- oriëntasies}

Volgens Allport (1960:263) kan die ontstaan van hierdie twee basiese godsdiens-oriëntasies teruggelei word na die tipe redenasies en ingesteldhede waaraan ' $n$ kind blootgestel is (veral wanneer hy gewoond geraak het aan bevooroordeelde redenasies), asook die mate van sekuriteit wat 'n persoon as kind geniet het. Wanneer 'n kind onsekerheid, minderwaardigheid in status en wantroue beleef het, skep dit by hom psigologiese behoeftes. Hierdie behoeftes gaan bevredig word wanneer hy ervaar dat God aan sy kant is en dat God se guns vir hom spesiaal en anders is (Allport, 1960:264). So 'n kind toon gevolglik 'n affiniteit vir 'n meer eksklusiewe godsdiens. In hierdie geval is godsdiens nie 'n meestermotief op sy eie nie, maar eerder instrumenteel vir die totstandkoming van die verskeidenheid vorme van eie-belang (Allport, 1973:54 e.v., 1960:264). 'n Predikant met 'n ingesteldheid van eiebelang sal die Skrif waarskynlik ook selektief gebruik en ook by die gemeente 'n gesindheid van eiebelang en selektiewe gebruik van die Skrif stimuleer. Godsdiens het dan alleen ekstrinsieke (uitwendige, oppervlakkige) waarde en daarom is dit 'n ekstrinsieke godsdiens.

Ook die intrinsiekgeoriënteerde persoon kan in 'n huis grootword en as kind ook selfgesentreerd of gesinsgesentreerd - soos alle kinders wees. Tog is hier 'n verskil: hierdie kind ervaar sekuriteit en geborgenheid binne sy ouerhuis en ervaar gevolglik nie in ander mense 'n bedreiging nie (Allport, 1960:264). Vir só 'n persoon is dit nie nodig om godsdiens te gebruik om homself te beskerm nie. Al het hy vrese en kwellinge, gaan dit hom nie pootjie nie; hy aanvaar dit as normale beproewinge van die lewe. Uiteindelik lei so 'n ingesteldheid tot die aanvaarding van ander. Die dogma wat hy handhaaf, gaan gepaard met nederigheid. Hierdie oriëntasie is nie beperk tot enkele segmente van eiebelang nie (Allport, 1960:265).

\subsection{Die aard van ekstrinsieke en intrinsieke godsdienstiggeoriën- teerdes}

Die persoon wat godsdienstig ekstrinsiek georiënteerd is, is die een wat wel aan 'n kerk behoort, maar ter wille van nie-godsdienstige, ekstrinsieke (uitwendige) motiewe. Hy stel sy godsdiens ondergeskik aan die 
bevrediging van sy eie behoeftes en motiewe om daaraan diensbaar te wees. Allport beskou hierdie tipe persoon as geestelik meer onvolwasse (vgl. Fleck, 1981:66). Hierdie tipe mens is gewoonlik die ongeërgde randlidmaat, is normaalweg konserwatief in sy lewensuitkyk en menslike prestasie is vir hom 'n hoë deug. God figureer binne so iemand se raamwerk as die Beloner van mense wat presteer. Enige iets of iemand wat hierdie lewenswyse bedreig, word as 'n gevaar beskou. Hierdie eksklusiwiteit is die teelaarde vir 'n kritiese en selfs polemiese ingesteldheid teenoor buitegroepe.

Hierteenoor het 'n intrinsieke godsdiens intrinsieke (innerlik-egte) waarde. Die intrinsiek georiënteerde persoon stel sy eie motiewe en behoeftes ondergeskik en diensbaar aan sy godsdiens. Hierdie persoon word deur Allport gesien as geestelik meer volwasse (vgl. Fleck, 1981:66) en sy godsdiens is ' $n$ meestermotief in sy lewe sodat sy morele lewe deur sy godsdiens bepaal word. Sy godsdiens is alles insluitend en nie bloot 'n geïsoleerde segment (naas ander segmente) van sy lewe nie. Verdraagsaamheid is een van sy natuurlike karaktertrekke. Hy besef ook die kompleksiteit van sy godsdiens en is voortdurend besig met ' $n$ ondersoek en reorganisasie van sy godsdiens.

\subsection{Uitbreiding van die intrinsiek-/ekstrinsiekskema}

Allen en Spilka (1967:191 e.v.) het 'n ondersoek gedoen na godsdiens en menslike vooroordele of predisposisies en twee groepe onderskei: die toegewydes (committed) en die saamstemmendes (consensual). Fleck (1981:68 e.v.) het aangesluit by Allport se onderskeiding, asook by Allen en Spilka se onderskeiding en die twee klassifikasies gekombineer om 'n trigitomiese gesigspunt te formuleer, wat soos volg daar uitsien:

- Die eerste dimensie is die intrinsiek-toegewyde persoon (wat ooreenstem met Allport se intrinsieke persoonlikheid, sowel as met Allen en Spilka se toegewyde persoonlikheid). Hierdie dimensie het betrekking op die abstrakte en rasionele eienskappe van godsdiens wat niedubbelsinnig, goed gedifferensieer en verskeidenheidverdraagsaam is. Hierdie persoon se godsdiens behels 'n persoonlike en opregte verbintenis tot godsdienstige waardes wat 'n meestermotief in sy lewe word. Hy openbaar voorts 'n besondere sin vir perspektief en is oop en soepel.

- Die tweede dimensie is die saamstemmende persoon (wat ooreenstem met Allen en Spilka se saamstemmende persoonlikheid). Hierdie dimensie reflekteer 'n godsdiens wat moet meewerk tot persoonlike gemak en misplaaste gerustheid. Besondere aansluiting word gevind by godsdienstige outoriteit, geïnstitusionaliseerde praktyke en 
seremoniële en rituele praktyke. Vir hierdie persoon word die godsdiensgroep gebruik vir persoonlikheidsondersteuning en as 'n hawe van gemak, gerief en geborgenheid. Fleck (1981:70) stel verder dat hierdie persoon gekenmerk word deur 'n oppervlakkige en beperkende manier van dink wat gevolglik uitloop op 'n eenvoudige, konformistiese ingesteldheid teenoor die lewe.

- Die derde dimensie is die ekstrinsieke persoon (wat ooreenstem met Allport se ekstrinsieke persoonlikheid). Hier word godsdiens gesien as 'n bruikbaarheidskommoditeit wat ter wille van selfdiens ingespan word. Fleck (1981:70) beklemtoon veral die motief van sosiale voordele soos status, aanvaarding in die gemeenskap en die wen van klandisie vir 'n besigheid.

Fleck (1981:71) verwys na twee onafhanklike faktor-analitiese studies wat hierdie driedimensionele klassifikasie ondersteun. Hy het self 'n vierfaktorskaal ontwerp (die saamstemmende kategorie is in twee groepe verdeel) om godsdienstige persoonlikheid te meet.

\section{Opsommend}

Die bedoeling was dat bostaande illustrasie die waarde van die tussenvlak tussen die Teologie en die Psigologie sou bevestig. Hierdeur is gepoog om aan te toon dat die erkenning van hierdie tussenvlak die deur oopmaak vir perspektiefverbreding en insig by die teoloog, wanneer hy die kerklike praxis vanuit die perspektief van die Praktiese Teologie bestudeer. Die erkenning van die tussenvlak hou verder verband met die skep van begrip, gemotiveerdheid en gerigtheid by sodanige teoloog wat uiteindelik sy bedieningseffektiwiteit verhoog en 'n verbeterde en 'n Skriftuurlik meer korrekte kerklike praxis tot gevolg het.

Wanneer slegs byvoorbeeld die praxis ontleed word (met hoeveel noukeurigheid en moeite ook al), gaan dit van weinig betekenis wees. Eers wanneer hierdie situasie-analise in wisselwerking gebring word met die teologiese teorie, het dit funksionele waarde. Net so het die teologiese arbeid wat in 'n lugleegte geskied weinig funksionele waarde. Eers wanneer dit met die empirie gekonfronteer word, word dit kontekstueel en relevant. Praktiese Teologie onderskei homself van ander teologiese dissiplines daarin dat hy hierdie funksionele tussenvlak betree met die doel om effektief te bedien, sonder om sy normerende aard te laat affekteer.

\section{Bibliografie}

ALLEN, R.O. \& SPILKA, B. 1967. Committed and consensual religion. A specification of religion-prejudice relationships. Journal for the Scientific Study of Religion, 6:191-206. 
ALLPORT, G.W. 1960. Personality and social encounter. Boston, MA : Beacon.

ALLPORT, G.W. 1970. The religious context of prejudice. (In Sadler, W.A., ed. Personality and religion. The role of religion in personality development. New York : Harper \& Row. p. 73-88.)

ALLPORT, G.W. 1973. Traits revisited. (In Brown, L.B. Psychology and religion. Harmondsworth : Penquin. p. 54-57.)

BROWNING, D.S. 1983. Pastoral theology in a pluralistic age. (In Browning, D.S., ed. Practical theology. San Francisco, CA : Harper \& Row. p. 187-202.)

CARTER, J.D. \& NARRAMORE, B. 1979. The integration of psychology and theology. Grand Rapids, MI : Zondervan.

COLE, D.T. 1998. Against the integration of psychology and Christianity: A bold proposal for an alternative paradigm. Journal of Psychology and Christianity, 17(3):210-219.

CRABB, L. 1987. Understanding people. Deep longings for relationship. Grand Rapids, MI : Zondervan.

DINGEMANS, G.D.J. 1986. In de leerschool van het geloof. Mathematiek en vakdidactiek voor catechese en kerklijk vormingswerk. Kampen : Kok.

ELLENS, J.H. 1997. The interface of psychology and theology. Journal of Psychology and Christianity, 16(1):5-17.

ELLIS, A. 1996. Better, deeper, and more enduring brief therapy. The rational emotive behavior therapy approach. New York : Brunner/Mazel.

FIRET, J. 1980. De plaats van de practische theologie binnen de theologische faculteit. (In Van Andel, C.P. Geense, A. \& Hoedemaker, L.A., eds. Praktische theologie. Een bundel opstellen over plaats en praktijk van de christelijke gemeente. 's-Gravenhage : Boekencentrum. p. 9-27.)

FLECK, J.R. 1981. Dimensions of personal religion. (In Fleck, J.R. \& Carter, J.D. Psychology and Christianity - Integrative readings. Nashville TN : Abingdon. p. 66-80.)

FREUD, S. 1970. Obsessive actions and religious practices. (In Sadler, W.A., ed. Personality and religion. The role of religion in personality development. New York : Harper \& Row. p. 47-56.)

FROMM, E. 1970. Individual and social Narcissism. (In Sadler, W.A., ed. Personality and religion. The role of religion in personality development. New York : Harper \& Row. p. 117-134.)

GIBSON, H.M. 1995. Personality and Christian fundamentalism. Journal of Empirical Theology, 8(2):58-81.

HEITINK, G. 1984. Pastoraat als hulpverlening. Inleiding in de Pastorale Theologie en Psychologie. Kampen : Kok.

HEITINK, G. 1993. Practical Theology. History, theory, action domains. Grand Rapids, MI : Eerdmans.

HEITINK, G. 1998. Pastorale zorg. Theologie - differentatie - praktijk. Kampen : Kok.

HEYNS, L.M. \& PIETERSE, H.J.C. 1990. A primer in Practical Theology. Pretoria : Gnosis.

HILTNER, S. 1958. Preface to Pastoral Theology. New York : Abingdon.

JAMES, W. 1929. The varieties of religious experience. New York : The Modern Library.

JONKER, H. 1983. Theologische praxis. Problemen, peilingen en perspektiven bij kenterend getij. Nijkerk : Callenbach.

JONKER, W.D. 1968. Theologie en praktijk. Een peiling van het theologisch karakter van de diakoniologische vakken. Kampen : Kok. 
JUNG, C.G. 1970. Christ, a symbol of the self. (In Sadler, W.A., ed. Personality and religion. The role of religion in personality development. New York: Harper \& Row. p. 135-145.)

KUYPER, A. 1909. Encyclopaedie der Heilige Godsgeleerheid III. Kampen : Kok.

LOUW, D.J. 1996. Praktiese Teologie in sosiologiese perspektief - enkele kritiese vrae met die oog op teologiese teorievorming. Praktiese Teologie in S.A., 11(1):23- 37.

LOUW, D.J. 2001. The challenge of a global economy to a practical theological ecclesiology: Pastoral care to internet and the living human web. Ongepubliseerde lesing gelewer voor die Werkgemeenskap vir Praktiese Teologie, Januarie 2001.

McCANN, D.P. 1983. Practical theology and social action. (In Browning, D.S., ed. Practical Theology. San Francisco, CA : Harper \& Row. p. 105-125.)

MÖLLER, A.T., red. 1996. Perspektiewe oor persoonlikheid. Isando : Heinemann.

MÖLLER, F.P. 1964. 'n Dogmaties-kritiese beoordeling van die betekenis van die Psigologie vir die pastoraat. Pretoria : Universiteit Pretoria. (Proefskrif - D.D.)

NEL, M. 1991. Die wisselwerking tussen teorie/praxis in die Praktiese Teologie. Ongepubliseerde lesing voor die Werkgemeenskap vir Praktiese Teologie in SA. Pretoria : Vista Universiteit.

OGLETREE, T.W. 1983. Dimensions of Practical Theology: Meaning, action, self. (In Browning, D.S., ed. Practical Theology. San Francisco, CA : Harper \& Row. p. 83-101.)

PIETERSE, H.J.C. 1991. Die wetenskapteoretiese grondslag van die Praktiese Teologie. Praktiese Teologie in SA, 6(1):38-51.

PIETERSE, H.J.C. 1994. Metateorie as wetenskapsbenadering in die Praktiese Teologie. Praktiese Teologie in SA, 9(1):93-100.

PRUYSER, P.W. 1968. A dynamic psychology of religion. New York : Harper \& Row.

ROSCAM ABBING, P.J. 1981. Psychologie van de religie. Godsdienstpsychologie in verband met filosofie en theologie. Assen : Van Gorcum.

SADLER, W.A. 1970. The scientific study of religion and personality. (In Sadler, W.A., ed. Personality and religion. The role of religion in personality development. New York : Harper \& Row. p. 1-31.)

SCHLEIERMACHER, F.D.E. 1977. Kurze Darstellung des Theologischen Studiums zum Behuf Einleitender Vorlesungen. Kritische Ausgabe herausgegeben von Heinrich Scholz. Darmstadt : Wissenschaftliche Buchgesellschaft.

SMITH, W.C. 1978. The meaning and end of religion. Minneapolis, MN : Fortress.

SMUTS, A.J. 1989. 'n Woord vooraf. (In Smuts, A.J., red. Predikant en pastorale praktyk. Pretoria : Academia. p. vii-ix.)

TRIMP, C. 1972. Diakoniologie. (In Trimp, C., red. Oriëntatie in de theologie. Groningen : De Vuurbaak. p. 146-165.)

VAN DER VEN, J.A. 1988. Practical Theology: from applied to empirical theology. Journal of Empirical Theology, 1(1):7-27.

VAN DER VEN, J.A. 1993. Ecclesiology in context. Grand Rapids, MI : Eerdmans.

VENTER, C.J.H. 1992. Diakoniologie en rasionaliteit - 'n Verkenning. In die Skriflig, 26(1):29-51.

VENTER, C.J.H. 1995. Die Woord in die werklikheid. Wetenskapsteoretiese perspektiewe op Diakoniologie. In die Skriflig, 29(1\&2):181-202.

VENTER, C.J.H. 1996. Uitkringende liefdesbetoon. Kommunikatiewe handelinge in diens van die onderlinge liefdesgemeenskap in die kerk. Pretoria : RGN. 
ZERFASS, R. 1974. Praktische Theologie als Handlungswissenschaft. (In Klostermann, F. \& Zerfass, R. Praktische Theologie heute. München : Kaiser. p. 164-177.)

ZWERGEL, H.A. 1976. Religiöse Erziehung und Entwicklung der Persönlichkeit. Psychologischer Leitfaden für Religionslehrer und Praktische Theologen. Köln : Benziger.

\section{Kernbegrippe:}

Praktiese Teologie

Psigologie

Psigologie en Praktiese Teologie; verhouding; tussenvlak Psigologie: verhelderende funksies

\section{Key concepts:}

Practical Theology

Psychology

Psychology and Practical Theology; interface and relation; Psychology: illuminating functions 